\title{
LIMA BARRETO'S MARGINÁLIA: THE MAGAZINE WRITER'S DREAM
}

\section{FELIPE BOTELHO CORRÊA}

King's College London

Londres, Reino Unido

\begin{abstract}
This article analyses Lima Barreto's lifelong relationship with magazines not only as a contributor, but also as a founder, editor, and even collector of these ephemeral publications. His debut in 1902 as a writer for his college magazine, $A$ Lanterna, and his death in 1922 while contributing to A.B.C. and Careta, can be considered symbolic events that epitomize the birth and death of a career wholeheartedly dedicated to this métier. A central argument is that it is highly significant that Barreto published his works in magazines more often than in newspapers. To him, magazines were stores of rhetorical weapons, artefacts that could confront the intellectual values established and concentrated in Rio de Janeiro.
\end{abstract}

Keywords: Lima Barreto; Magazines; First Republic.

\section{A MARGINÁLIA DE LIMA BARRETO: O ESCRITOR E SUA SONHADA REVISTA}

Resumo: Este artigo analisa a relação que Lima Barreto manteve, ao longo de sua carreira como escritor, com revistas de variados tipos. Além de colaborador, Lima Barreto também foi fundador e editor de publicações efêmeras que marcaram seu projeto literário. Sua iniciação em 1902 na revista A Lanterna e sua morte em 1922, enquanto colaborava com os semanários Careta e A.B.C., são eventos simbólicos que sintetizam vida e morte de uma carreira dedicada a este métier. $O$ argumento do artigo é que é altamente significativo o fato de Lima Barreto ter publicado a maior parte de seus textos em revistas e não em jornais diários da época. Para ele, as revistas eram artefatos que podiam confrontar os valores intelectuais que reinavam no Rio de Janeiro da Primeira República.

Palavras-chave: Lima Barreto; revistas; Primeira República.

I $\mathrm{n}$ a world where mass circulation of photographic images was still scarce, but rapidly growing, when postcards were a brand new form of media, turn-of-the-century illustrated magazines fascinated their domestic readers but also, and perhaps more expressively, faraway readers. Better paper quality, higher definition images and wider international 
circulation meant that illustrated magazines regularly reached readers that newspapers could never reach on a regular basis.

Fascinated by the images, many consumers adopted the habit of collecting cuttings from foreign periodicals to embellish their simple houses and decorate rooms. The young Lima Barreto participated actively in this common turn-of-the-century pastime. In early 1905 he was 23 years old and had only contributed to collegiate and amateur magazines. In April of that year, however, his first contributions to a large circulation periodical appeared. And yet, before his professional debut, he wrote an entry in his personal journal on the first day of that year:

Hoje, dia de ano-bom, levantei-me como habitualmente às sete e meia para as oito horas. Fiz a única ablução do meu asseio, tomei café, fumei um cigarro e li os jornais. Acabando de lê-los, arrumei as paredes do meu quarto. Preguei aqui, ali, alguns retratos e figuras, e ele tomou um aspecto mais garrido. Há, de misturas com caricaturas do Rire e do Simplicissimus, retratos de artistas e generais. Não faz mal; nesse aspecto baralhado ele terá o aspecto da vida ou da letra " $A$ " do dicionário biográfico, que traz Alexandre, herói de alto coturno, e um Antônio qualquer, célebre por ter inventado certa pomade. ${ }^{1}$

This was not an extraordinary habit at the time. In fact, while Barreto puts caricatures and pictures of generals side by side in his room, readers in Buenos Aires, for example, chose to combine "retratos de héroes populares, generales o reyes recortados de las revistas, una imagen de la virgen o un par de santos" to decorate their homes. ${ }^{2}$ Fascinated by the new circulation of mechanical images, readers in South America became collectors, bringing images of a variety of places, people, and statuses into the private sphere, the young Barreto being no different.

On New Year's Day, 1905, he was hopeful about the year that lay ahead of him while proudly describing his freshly decorated room. Rich in details, the personal journal reveals Barreto making his own collage using European sources, showing not only that he was an enthusiastic reader of literary and political magazines but also how to some extent his intellectual project was shaped by the success and satirical militancy of popular illustrated magazines.

The circulation between centre and periphery that was occurring at the international level was also taking place within peripheral countries like

${ }^{1}$ BARRETO, Obras Completas de Lima Barreto, vol. 14, p. 71.

${ }^{2}$ SCOBIE, Buenos Aires, del centro a los barrios, 1870-1910, p. 192. 
Brazil, where illustrated magazines fascinated people who not only lived in the capital but in other, far-flung places throughout the territory, bringing them information from the political centre of the country. In such a vast area, these popular magazines provided a writer one of the very few possibilities to communicate with a truly nationwide readership, sometimes even reaching other countries either sporadically or regularly.

Barreto's comments quoted above are relevant insofar as they are symptomatic of the role that images and popular magazines played in his career. When decorating his room, he uses photographs and caricatures to make it more elegant, but he also seems to be transforming his wall into the facsimile of an illustrated magazine, with sections on politics (generais), celebrities (artistas), cartoons (caricaturas), and advertisements (pomadas). His reference to generals and ordinary merchants sharing the same space mixing up Alexandres and Antônios, political leaders and anonymous figures - shows that he was very familiar with the format that was being used by Simplicissimus ${ }^{3}$ and Le Rire ${ }^{4}$ and other popular illustrated magazines that emerged during the turn-of-the-century magazine boom. ${ }^{5}$

\footnotetext{
${ }^{3}$ Simplicissimus, was founded in Germany in April 1896 and published until 1967, with a hiatus from 1944-1954.

${ }^{4}$ Published as an illustrated satirical weekly from October 1894 to well into the 1950s, Le Rire was founded in Paris by Felix Juven.

${ }^{5}$ Magazines were by no means a novelty at the turn of the century, but the success of these cheap, well-printed, illustrated magazines that reached massive circulations certainly was. Although various factors might explain this complex change, the growth of national advertising, new printing technologies, and an increase in circulation are widely accepted as the most important aspects of this shift. Starting in the USA and Europe, this watershed moment spread to other countries in Latin America, where magazines achieved regular domestic distribution, following nationwide industrial expansion, epitomised by national exhibitions.
} 

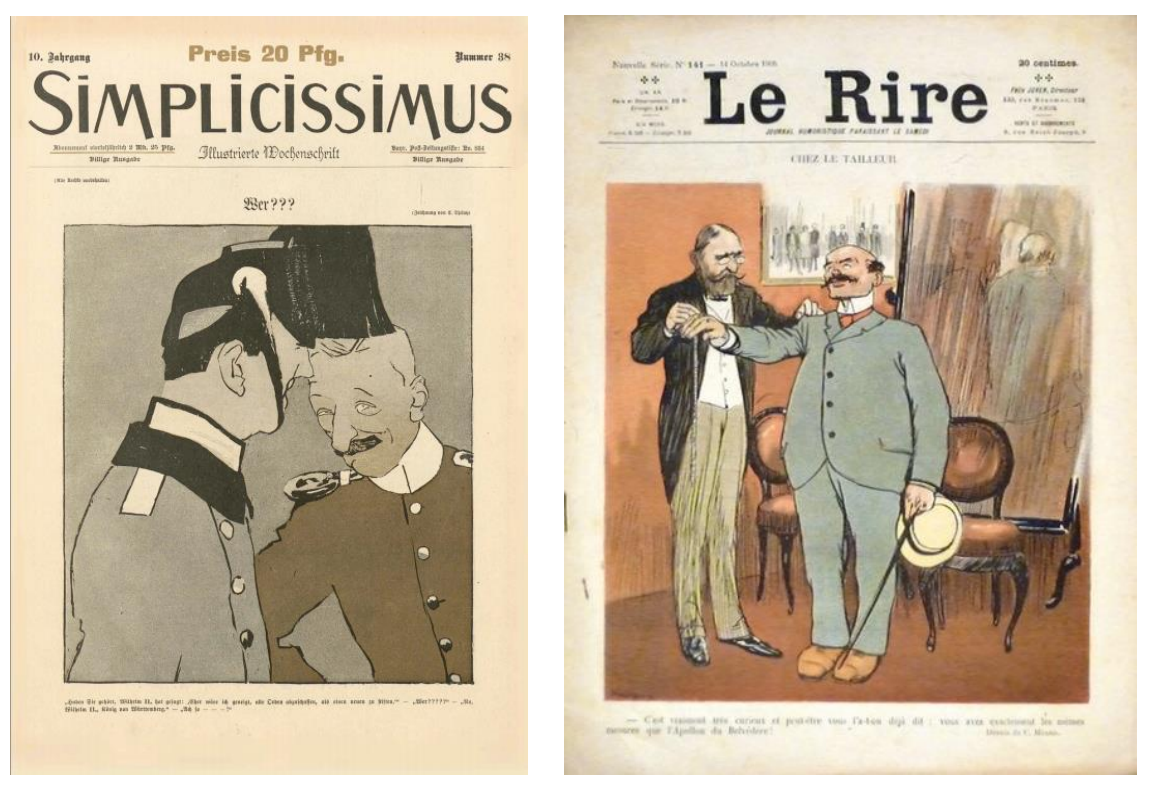

Front covers of Simplicissimus and Le Rire in 1905.

In Brazil, this new model of magazine publishing became more apparent at the beginning of the 1900s, with O Malho, launched in 1902, followed by many others, including Fon-Fon in 1907, and Careta in 1908.6 With a growing domestic circulation and the aim of persuading advertisers to invest in them, these magazines actively encouraged a clearer distinction between themselves and daily newspapers and thus catered to a nationwide, rather than local, readership.

Intuitively or not, the entry in Barreto's diary expresses a sensibility that clearly had been marked by the turn-of-the-century magazine boom. Apart from daily newspapers, the three main types of periodicals he read throughout his life were precisely the critical reviews that emerged in the mid-nineteenth century, the little magazines, ${ }^{7}$ and the popular illustrated magazines from the turn of the century. Little magazines and critical reviews were accessible only to the small cultivated part of the population while the illustrated magazines could be consumed by a wider range of people. These types of magazines were the template for what could have been Barreto's most important and representative periodical: the magazine Marginália,

\footnotetext{
${ }^{6}$ Absent from this list is Revista da Semana (1900-1962) as this magazine circulated jointly with Jornal do Brasil until 1915, at which point it began its independent distribution.

7 These magazines published texts of relatively unknown writers, often without a commercial agenda. They could be eccentric in terms of format, printing, distribution method, ideas and content. They were, in general, issued in an amateur spirit; their editors were concerned less with making money from them than with merely keeping them alive as vehicles for their literary expression and that of their friends. See more in BROOKER, The Oxford Critical and Cultural History of Modernist Magazines.
} 
which he envisioned in 1917, and will be discussed in detail further in this article.

Barreto's objective of reaching a large readership was an intrinsic part of his intellectual project as a writer. As he states in his well-known short manifesto "Amplius!", he wanted to become part of the "patrimônio comum do espírito dos contemporâneos", doing so by using "uma língua inteligivel a todos". ${ }^{8}$ Repeated with some variations in many parts of his oeuvre, including in his lecture "O destino da literatura", 9 this motto represents one of the pillars of his intellectual project: to become a truly popular writer. He wanted to be read by all classes and races, communicating what he felt and observed to the largest possible number of readers, because according to him "a arte literária se apresenta com um verdadeiro poder de contágio que a faz facilmente passar de simples capricho individual, para traço de união, em força de ligação entre os homens".$^{10}$ As Oakley (1998) points out, this intellectual mission was based particularly on Barreto's reading of Tolstoy's What is Art? (1904), and displayed in Barreto's novels and short stories. It is worth noting, however, that it was not possible to fully achieve this mission through books alone at that time in Brazil since the print culture during the First Republic was mainly restricted to a small number of readers.

In order to carry out his crusade, Barreto embraced the power of nationwide magazines to engage readers of all kinds. These magazines often featured numerous photographs and comic cartoons, which appeared along texts in a symbiosis that influenced not only other caricaturists and photographers but also writers like Barreto, who regarded them as useful tools for communicating with the masses.

Apart from his 1905 diary entry, other references to caricatures and popular magazines can be found throughout his oeuvre. In an article published in A Estação Teatral in 1911, he shows great interest in and knowledge of cartoonists. Although this short piece focuses on works by Julião Machado, a Portuguese illustrator based in Brazil, it also refers to many European, Latin American, and Anglo-American caricaturists and magazines, often in detail, demonstrating his great interest in this form of art. At certain points in the text, one can infer that Barreto has a collection of magazines in front of him while he writes: "Tenho aqui a reprodução do

${ }^{8}$ BARRETO, cit., vol. 6, p. 35.

9 "Em que pode a Literatura [...] contribuir para a felicidade de um povo, de uma nação, da humanidade, enfim? / São perguntas naturais e espontâneas que não há um homem que as não tenha feito no seu foro intimo e que eu mesmo as fiz, quando, há cerca de vinte anos, me pus juvenilmente a escrever para o público em revistas e jornalecos que nasciam, eram lidos e morriam". BARRETO, cit., vol. 13, p. 55-56.

${ }^{10}$ BARRETO, cit., vol. 13, p. 62. 
desenho do famoso Tenniel, do Punch", ${ }^{11}$ or "Este artigo devia ser ilustrado e então eu queria pôr aqui aquele famoso desenho de Daumier, tratando de Napoleão III e a França". ${ }^{12}$ Barreto eventually had his texts surrounded by illustrations in Careta, but in A Estação Teatral he could not have his article illustrated by Daumier's drawing below.

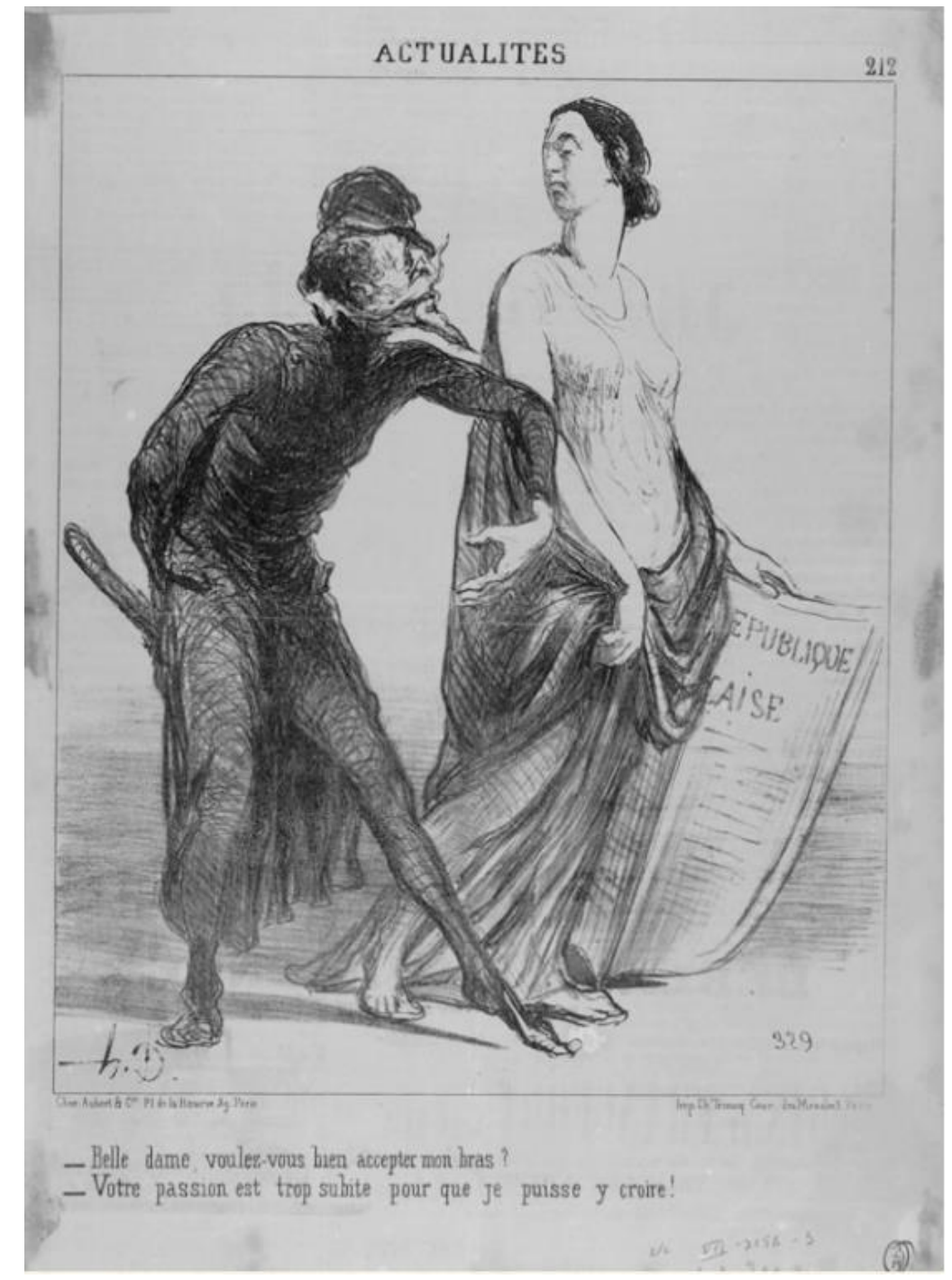

Actualités by Honoré Daumier. Le Charivari, 25 September $1851 .{ }^{13}$ Caption: - Belle dame, voulez-vous bien accepter mon bras?

- Votre passion est trop subite pour que je puisse y croire!

These references are proof that Barreto paid close attention to caricatures and considered them part of his studies into popular aesthetics aimed at large audiences. In fact, caricature was one of the central concerns

${ }^{11}$ BARRETO, Crônicas completas, vol. 1, p. 85.

${ }^{12}$ Idem, p. 87.

${ }^{13}$ Available from www.daumier-register.org. Daumier Register Number 2153. 
of his ideas about "homens de arte e coisas artísticas". ${ }^{14} \mathrm{He}$ mentions this fact at the very beginning of the article and develops a critique of Julião Machado's works, noting their lack of simplicity and clarity, two of the most important characteristics for a Tolstoyan artist like Barreto. ${ }^{15}$ For Barreto, "os grandes desenhistas, cômicos ou não, que notam diariamente a vida, o fazem com simplicidade de concepção e clareza de execução".16

Thus it is clear that Barreto saw caricature as a powerful critical tool if conceived with a focus on simplicity and clarity, but his idea was not shared by conservative writers who regarded "processos do jornalismo" as inappropriate for prose fiction. ${ }^{17}$ In fact, for Barreto the very idea of prose fiction could not be conceived when unconnected to the surrounding reality as lived by the author, and the personal history and experience of each writer. It is in this sense that Barreto's experience as a contributor to periodicals was so closely connected with his literature, making the task of defining the genre in which he was writing very difficult. There is an ambivalence between fiction, autobiography, satire, and journalism, which deeply marked Barreto's short pieces and novels.

This distinctive ambivalence can be seen as one of the reasons why Barreto linked himself more often with magazines than newspapers. He indeed published many of his great novels in newspapers, but from the very beginning of his career he contributed many more short texts to magazines, which were more receptive to this writing perspective.

Barreto's first contributions to a magazine with a large and regular circulation would only start in April 1907, when he was invited by the poet and journalist Mário Pederneiras to be the secretary of Fon-Fon. However, Barreto's position on the staff apparently did not last for long. In a draft letter to Pederneiras dated 20 June 1907, Barreto explains the reasons that supposedly led him to stop contributing to Fon-Fon. He complains that his texts were not being published, regardless of his efforts to praise the editors. Feeling unappreciated, he resigned from his position.

His experience at Fon-Fon in 1907 probably opened doors for Barreto at Careta, which was published by the same man: Jorge Schmidt (who also published Kósmos). Francisco Barbosa argues that there is a link between Barreto leaving Fon-Fon and his initiative to start the little magazine Floreal

\footnotetext{
${ }^{14}$ BARRETO, cit., vol. 1, p. 85.

15 In chapter XV of What is Art?, Tolstoy defines these attributes, along with individuality and sincerity, as the most important in what he defined as true art. TOLSTOY, What is Art?, p. 152.

16 BARRETO, cit., vol. 1, p. 85.

${ }^{17}$ BARRETO, cit., vol. 6, p. 34.
} 
in partnership with friends. ${ }^{18}$ There is, however, evidence that Barreto never detached himself from Fon-Fon's editorial team. In 1921, for example, he still received requests from writers asking him to recommend the publication of their texts counting on Barreto's "prestígio nas redações de Fon-Fon $e$ Careta". ${ }^{19}$ In this sense, it is more plausible to argue that Floreal represented above all a reaction against the rules imposed by powerful daily newspapers, not popular magazines like Fon-Fon. The experience at Fon-Fon worked more as an incentive to use the magazine format more audaciously, fighting intellectual hegemony. This incentive led Barreto to take on the responsibility of starting up and editing a periodical for the first time in his life.

\section{From Writer to Director of Floreal}

On 25 October 1907, three months after Barreto supposedly left Fon-Fon, the first issue of Floreal came out. Although it was a collective initiative, Barreto was the main writer behind the project, and the one in charge, as explicitly demonstrated on the front cover. Since they could not count on the support of advertisers, the group of writers had to finance the magazine themselves.

18 BARBOSA, A vida de Lima Barreto, p. 174.

19 Letter from his brother, Carlindo de Lima Barreto, 12 Jan 1921, MS 168, Arquivo Lima Barreto. 


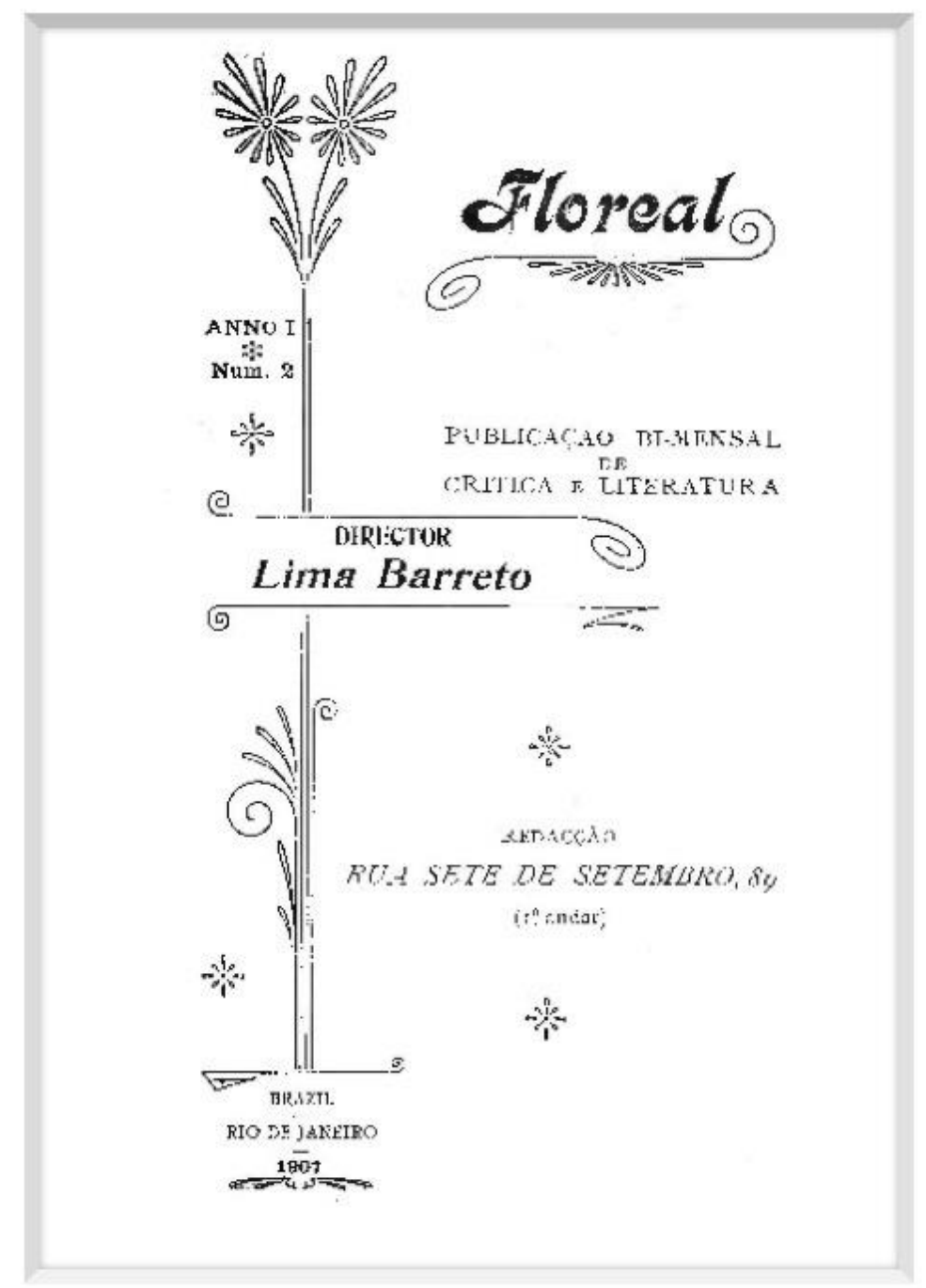

Cover of Floreal, 2 November 1907.

Barreto's disenchantment with large circulation newspapers is salient in his introductory article in the first issue, where he complains about the difficulties of getting published in daily media and justifies the founding of the magazine as "o nosso dever de nos publicar". ${ }^{20}$ On behalf of the group who sustained Floreal, Barreto writes a scathing critique of the way newspapers functioned at the time.

Cada um de nós está certo de que seria perfeitamente incapaz de levar emoções aos habitantes respeitáveis de Paracatút ${ }^{21}$ ou de atrair leitores da

\footnotetext{
${ }^{20}$ Floreal, 25 Oct 1907.

${ }^{21}$ Paracatú is a town in the state of Minas Gerais which had a fast growing economy and its own local newspapers such as Luzeiro and Paracatú at the turn of the century. See Mello. As minas reveladas: Paracatu no tempo.
} 
rua Presidente Barroso ${ }^{22}$ ou Marquês de Abrantes, ${ }^{23}$ mas, estamos certos também que essa média entre a sensibilidade obstruída de afastados compatriotas, o semi-analfabetismo de uns e a futilidade de outros, atualmente representada pelo jornal diário, não tem direito a distribuir celebridade e a estabelecer uma escala de méritos intelectuais. ${ }^{24}$

In this short passage, it is worth noting how Barreto emphasises his critique of daily newspapers, rather than weekly magazines, as the institutions which established a hierarchy of intellectual reputations. He refused to adhere to this powerful model of periodical publication that flattened individualities, but he had no problem contributing extensively to large circulation magazines like Fon-Fon, A.B.C., and Careta.

Francisco Barbosa claims that his "rápida passagem pela redação do Fon-Fon [...] acabou por convencê-lo da inutilidade do seu esforço de procurar o caminho da imprensa burguesa para a sua iniciação na carreira de escritor". ${ }^{25}$ However, Barreto's notes in his diary in 1908 shows that he enjoyed becoming part of Fon-Fon's staff as a way of putting into practice his plan to publish novels in instalments. The text does not mention whether he had stopped contributing to Fon-Fon and we do not know for sure if the letter to Mario Pederneiras was sent or not, as we only have access to a draft found in Barreto's archive. However, it seems that he did not regard his experience in Fon-Fon as irrelevant, as noted on 5 January 1908 in his diary:

O ano que passou foi bom para mim. [...] Neste andei um pouco, no caminho dos meus sonhos. Escrevi quase todo o Gonzaga de Sá, entrei para o Fon-Fon, com sucesso, fiz a Floreal e tive elogio do José Veríssimo, nas colunas de um dos Jornais do Comércio do me^s passado. Já comec ,o a ser notado. ${ }^{26}$

This entry shows no resentment against Fon-Fon, corroborating the idea that Floreal was founded to fight the daily newspapers' hegemony, something that to a certain extent Fon-Fon, Careta and A.B.C. also did. This is clear in the passage quoted above when Barreto describes daily newspapers as representatives of "sensibilidades obstruídas", "semi-

\footnotetext{
${ }^{22}$ Located in the neighbourhood of Cidade Nova in Rio de Janeiro, one of the poorest parts of the city at the time.

23 The richest neighbourhood in Rio at the turn of the century.

${ }^{24}$ Floreal, cit.

${ }^{25}$ BARBOSA, cit., p. 174.

${ }^{26}$ BARRETO, cit., vol. 14, p. 125.
} 
analfabetismos" and "futilidades". It could be argued that he bypassed magazines in his criticism because he was still working or had recently worked for a large circulation magazine, but even if this argument were true Barreto's text in Floreal shows that he was actively fighting for a new intellectual establishment in Brazil, which he believed could emerge from the increasing number of writers who could write with greater freedom when contributing to magazines.

Although Floreal was the first and only magazine that Barreto created, contributed to and edited himself, it was not the only magazine he conceived. A decade later, he outlined a new project. After Floreal, he contributed to various small periodicals, published some feuilletons in newspapers, and built a relationship with two important magazines: A.B.C. and Careta. The experience of working in these two national periodicals certainly influenced what would perhaps come to epitomise Barreto's aims regarding magazine publishing in Brazil.

In October 1917 he wrote a manuscript that presented and explained in detail the plans for a fortnightly publication that would be called Marginália. In conceptual terms, Marginália corroborates his desire to use magazines to attack the power established by conservative major newspapers. Although this aim matched that of Floreal, the editorial strategy had changed drastically over a decade. The manuscript is signed by "Os Editores", but taking into account Barreto's leadership in the project and the fact that it is his handwriting on the sheet of paper found in his archives, one can assume that it expresses Barreto's personal plans for a new periodical. The intended format for the publication is clearly indicated:

Na medida do razoável, não fugiremos aos moldes das publicações mais procuradas. Sem fazê-la semelhante aos chamados semanários humorísticos, nem tampouco aos modelos das grandes revistas clássicas o que no nosso meio é quase impossível -, esforçar-nos-emos por editar a Marginália de modo que, participando de um e outro gênero de publicidade, ela possa satisfazer o gosto de qualquer espécie de leitor, sem depender de nenhuma delas. ${ }^{27}$

This passage can be seen as Barreto's synthesis of his experiences as a contributor to many periodicals. He is in search of "qualquer espécie de leitor". Although the definition of two representative types of publication could have been drawn from Barreto's general view of the periodical print culture in Rio de Janeiro, his experiences with Careta in 1915 and A.B.C. in

${ }^{27}$ Arquivo Lima Barreto, MS 884. 
1916-17 should not be neglected. Both magazines targeted a large and varied readership, but on different levels. Careta certainly falls within the category of a humorous weekly magazine as described by Barreto, with a large nationwide circulation that critiqued those in power, including the daily press, as can be seen in the illustration below.

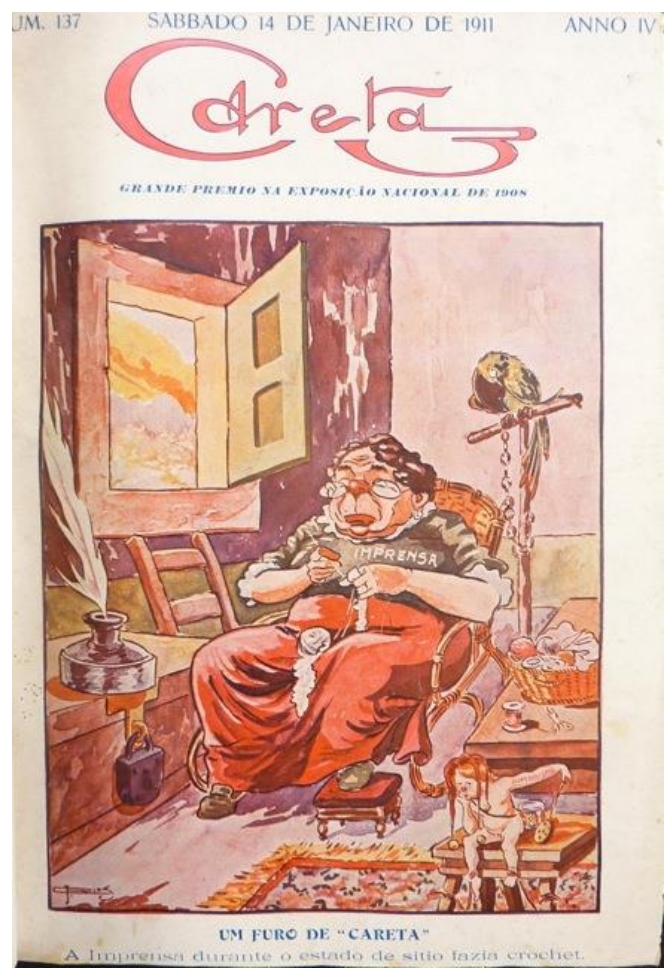

"Um furo de Careta: a Imprensa durante o estado de sítio fazia crochet." Careta, 14 Jan 1911.

However, Careta had a more varied focus, also working as a medium for information, entertainment, pictures, literature, fashion, and trade, whilst it was also very popular in the sense that it sold many issues weekly and reached a mass circulation. A.B.C., on the other hand, had a stronger analytical focus. It was a magazine written by intellectuals for cultivated readers, containing long, critical essays and appealing to a more restricted readership, despite being cheaper than Careta and frequently defined as an anarchist pamphlet. 


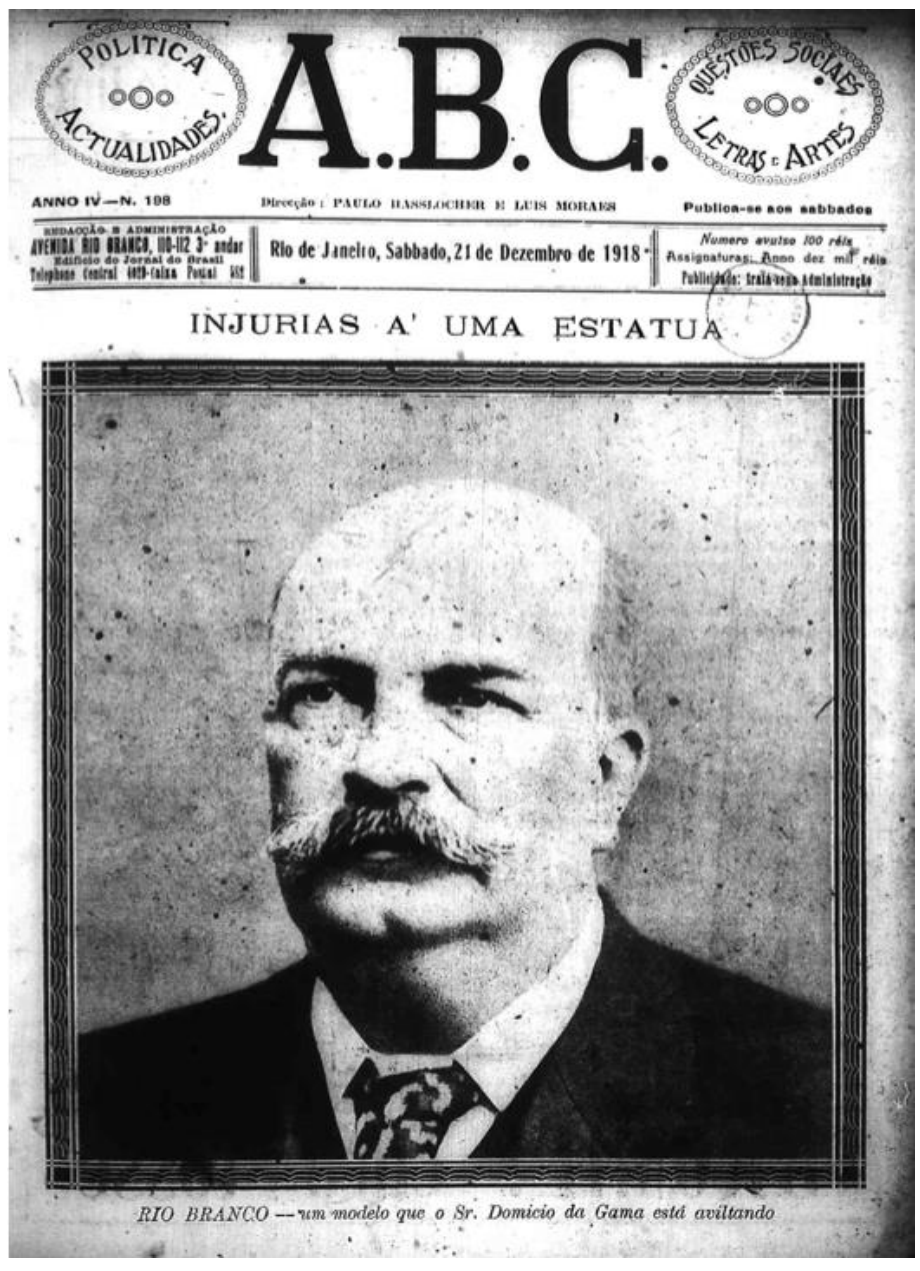

Rio Branco - um modelo que o sr. Domício da Gama está aviltando. A.B.C., 21 Dec 1918.

Barreto had not given any examples of what he regarded as a great classical magazine, but taking into account his numerous references to reviews such as Revue des Deux Mondes, Revue Philosophique, Nouvelle Revue Française, Revue des Cours et Conférences, Mercure de France, one can assume that he is probably referring to this type of publication. These were periodicals containing analyses of current affairs by prominent trend writers such as Brunetière, Guyau, Renan, Maupassant, and Taine. These five writers were named by Barreto as some of the most influential on his works, sometimes citing them as his intellectual guides. ${ }^{28}$ In his personal library, known as Limana, he lists volumes by each of these writers, which also include many issues of these "grandes revistas clássicas". ${ }^{29}$ For him, these reviews were sources of information about current debates in Europe and throughout the world. In his hands, these volumes were carefully read and

28 These names appear in various pieces by Barreto, especially in his lecture "O destino da literatura". BARRETO, cit., vol. 13, p. 51-69.

${ }^{29}$ Arquivo Lima Barreto, cit. 
studied, and many texts were cut out and organised in notebooks while illustrations of popular magazines were fixed on the walls of his room.

He mentions that this type of magazine - the review - was almost impossible to get published in Rio, probably taking his personal experience into account, since the format of Floreal was deliberately inspired by the review Mercure de France. ${ }^{30}$ The knowledge acquired through many years of contributions to magazines had influenced Barreto to search for an editorial solution that could be simultaneously intellectually challenging and have popular appeal. Barreto opts for "um aspecto baralhado", in the same way he arranged the pictures on his wall in 1905 in order to make sure there was something for all types of readers. In Marginália, he wants to shuffle two kinds of magazine formats into one, combining the popular magazine and the review.

He was also an avid reader of literary magazines, as he states subsequently in an article from 1919: "As pequenas revistas". He points out that it is precisely in this type of publication that one can find truth, novelty, and independence, but that these magazines would not flourish because "é dos nossos característicos mentais não dar importância senão ao consagrado e ao que é respeitável a toda a gente". ${ }^{31}$ Once more he criticises the Brazilian literati's old-fashioned habit of regarding newspapers as the main media for particular subjects:

A publicidade de ideias, de vistas, sobre isto ou aquilo, não tem importância senão quando é feita nos grandes jornais, mesmo para assuntos muitos especiais e restritos. Ora, acontece que os quotidianos respeitáveis têm mais o que fazer do que se preocupar com sonhos e outras maluquices; acresce ainda que são muitos a proclamá-los, de forma que o vazadouro natural, para as importunas atividades cerebrais, seria a revista. Entretanto, até hoje, uma grande revista não se pode manter no Rio e as pequenas que aparecem têm de levar uma vida precária e contrafeita, pois o público não as compra e não as toma a sério. / Alongarme, por aí, seria fazer um grande estudo que adio. ${ }^{32}$

In a few lines he shows that the literary publishing market in the capital was one of his concerns, demonstrating a considerable knowledge of

\footnotetext{
30 Barreto mentions that the format of Floreal was inspired by a foreign magazine. The layout of Floreal is almost identical to Mercure de France in 1907, including the name of the section "Revista da Semana" corresponding to "Revue de la semaine".

${ }^{31}$ BARRETO, cit., vol. 10, p. 156.

32 Ibidem.
} 
what kind of publication was relevant, but also regarding which formats were successful. This passage also shows how Barreto differentiated between magazines and newspapers in terms of their powers over and their penetration within society. For him, the daily press was still a bastion of the elite that had emerged in the late nineteenth century, and therefore was resistant to modern ideas and practices. Certainly, his aim was not to physically annihilate the daily press, but to question the power and hierarchies that these newspapers controlled in both the political and cultural arenas.

In Barreto's own words, magazines were the place for "sonhos e outras maluquices".$^{33}$ His desire to edit a magazine epitomises his effort throughout his career to renovate literary production in Brazil, something that was also emphasised later by other modernists, especially the group from São Paulo.

In order to engage in a consistent fight against what the daily press represented he had to propose a viable magazine format. The fact that periodicals like Careta and A.B.C. were more commercially successful than literary periodicals is perhaps one reason he wanted Marginália to be a combination of the two formats: popular without necessarily being humorous; literary without restricting itself to a small readership. In this sense, the programme of Marginália upholds one of the pillars of his intellectual project which aimed to produce a literature that could raise the curtains on political and literary current affairs in Brazil, to make the ordinary people aware of "tudo o que interessa o uso da vida, a direção da conduta e o problema do nosso destino". ${ }^{34}$ But in Marginália this intellectual project was connected necessarily to the need of reaching all kinds of readers, something that only a magazine of large circulation and popular appeal was likely to achieve:

O que nós desejamos é esclarecer fatos e opiniões, sob a luz de uma livre crítica, de forma que aqueles leitores, pouco enfronhados nos bastidores de certos aspectos da nossa vida e deles só tendo diante de si o fato bruto, possam melhor julgar o desenrolar dos acontecimentos politicos, literários $e$ outros, assim também as individualidades envolvidas nesses acontecimentos. ${ }^{35}$

The access to what was going on behind the scenes of political and literary life in Brazil was only available to a restricted group of politicians,

\footnotetext{
${ }^{33}$ Ibidem.

${ }^{34}$ BARRETO, cit., vol. 6, p. 35.

${ }^{35}$ Arquivo Lima Barreto, Ms. 884.
} 
journalists, and high-ranking civil servants. In this sense, Barreto proposed to work in a didactic way either disclosing or explaining to a wider audience what exists beyond the bare facts available in the daily press, which was mostly controlled by politicians. ${ }^{36}$ This passage gives a clue as to why he chose to name his magazine Marginália. According to his programme, the magazine would be driven by its responsiveness to raw facts which would be explained by the contributors while addressing a large readership. ${ }^{37}$ Thus, the articles in the magazine would not stand on their own, but would be permanently engaged with the "fatos brutos", clarifying what underpinned current events regarding politics and literature and the concomitant agenda behind them.

Barreto reveals in this passage that the magazine would function as the marginalia of mainstream Brazilian newspapers, just like the marginalia of a book might be composed of critical comments annotated in its margins. Indeed, compared to "quotidianos respeitáveis", magazines were already considered marginal publications in the capital. Barreto had known that the central power was concentrated in the daily press since his first days as a prose fiction writer, and expressed his frustration in Floreal in 1907. He knew that for writers at the early stages of their careers, newspapers were the main medium in which to legitimise their literary value:

Para se chegar a eles [jornais diários], são exigidas tão vis curvaturas, tantas iniciações humilhantes, que, ao se atingir as suas colunas, somos outros, perdemos a pouca novidade que trazíamos, para nos fazermos iguais a todo o mundo. Nós não queremos isso. Burros ou inteligentes, geniais ou medíocres, só nos convenceremos de que somos uma ou outra coisa, indo ao fim de nós mesmos, dizendo o que temos a dizer com a mais ampla liberdade de fazê-lo. ${ }^{38}$

Marginália was planned to epitomise Barreto's visceral commitment to the press as a reader, contributor, and editor, but also as a collector. If in 1905 he cut out and collected pictures from illustrated magazines, in 1917 he was seriously committed to continuing his collection by studying daily newspapers and writing their marginalia. It is from this period onwards that

\footnotetext{
${ }^{36}$ BARBOSA, cit.

${ }^{37} \mathrm{H}$. J. Jackson points out that "The broader principle underlying the conventional association of certain kinds of notes with certain kinds of books is the principle that marginalia must be responsive. They do not stand on their own, but are permanently attached to the text that stimulated them". JACKSON, Marginalia: Readers Writing in Books, p. 75.

${ }^{38}$ Floreal, cit.
} 
Barreto is more explicit about one of his most commonly employed methods to write journalistic texts, basing them on newspaper stories. In several pieces he clearly states to the reader how he selects the stories, as this extract from 1921 clearly demonstrates:

Este modesto artigo não passa de um ajustamento da marginália que fiz às notícias lidas por mim, nos quotidianos [...]. Era tal a falta de uma segura orientação nos que se digladiavam, que só tive um remédio para estudá-la mais tarde: cortar as notícias de jornais, colar os retalhos num caderno e anotar à margem as reflexões que esta e aquela passagem me sugerissem. Organizei assim uma "marginália" a esses artigos e notícias. ${ }^{39}$

This passage shows that he deliberately collected newspaper stories to build a marginalia, clearly highlighting the method that was used to underpin the magazine project of the same name. This method is present throughout Barreto's career, but more evident from 1916 onwards. For him the press was a source for acquiring knowledge, but not formal established academic knowledge. It represented knowledge of the structures of power in society. This is clearly stated in his project of writing a lengthy study on the "apedidos", a frequent and popular section in newspapers in which texts were published upon payment of a fee and where the editors exempted themselves from responsibility for the content:

Quando tiver tempo e dinheiro, hei de fazer um estudo completo sobre os apedidos, num largo programa que abranja as origens dos mesmos, os colaboradores, o estilo destes; a influência da célebre seção nos grandes fatos políticos, administrativos, sociais, forenses etc., da vida geral do Brasil. / [...] Documentarei a asserção de que a Maioridade, a Lei do Ventre Livre, Treze de Maio, o Quinze de Novembro, até o Sete de Setembro, [...] tudo isto e mais alguma coisa foram obra dos "apedidos". [...] a fim de executar a contento de todos não deixo nunca de ler os "apedidos" e recortá-los arquivando os retalhos. De resto, neles vou buscar elementos para o estudo da vida doméstica, comercial e sentimental da nossa sociedade. ${ }^{40}$

As a collector of stories published in the daily papers, Barreto actively selected content that would be part of his research as a public writer. Reading, selecting, and commenting on the stories was a method of critical

\footnotetext{
${ }^{39}$ BARRETO, cit., vol. 12, p. 32.

${ }^{40}$ BARRETO, Mansão Olímpica e os apedidos.
} 
observation that Barreto developed to successfully address the scattered readership of the magazines for which he wrote.

From Fon-Fon to Careta, and from Floreal to A.B.C., Barreto clearly focused on magazines and their potentialities to disseminate a dissonant, critical voice. His numerous short texts had an important role in developing easy communication with ordinary readers of his time. This idea is clearly expressed in the words of the protagonist of Barreto's last novel: Cemitério dos vivos. There, Vicente Mascarenhas describes his dilemma as an intellectual who had to choose between seeking a sophisticated art that would only achieve an exclusive audience, and an accessible art that could be enjoyed by a wider readership. He then explains why he momentarily left aside his goal of writing books that could "ferir a Ciência nas suas bases $e$ contestar-lhe esse caráter de confidência dos Deuses", 11 and started to contribute to magazines:

Veio-me a reflexão de que não era mau que andasse eu a escrever aquelas tolices [em revistas]. Seriam como que exercícios para bem escrever, com fluidez, claro, simples, atraente, de modo a dirigir-me à massa comum dos leitores, quando tentasse a grande obra, sem nenhum aparelho rebarbativo e pedante de fraseologia especial ou um falar abstrato que faria afastar de mim o grosso dos legentes. [...] Seria muito melhor que me dirigisse ao maior número possível, com auxílio de livros singelos, ao alcance das inteligências médias com uma instrução geral, do que gastar tempo com obras só capazes de serem entendidas por sabichões enfatuados, abarrotados de títulos e tiranizados na sua inteligência pelas tradições de escolas e academias e por preconceitos livrescos e de autoridades. Devia tratar de questões particulares com o espírito geral e expô-las com esse espírito. ${ }^{42}$

This passage is highly significant for clarifying the role of magazines in Barreto's intellectual project. He regarded writing in magazines as a training exercise to communicate his ideas to the masses, requiring a constant effort to write with clarity, fluency, and simplicity in order to appeal to a wide range of readers: the same characteristics Barreto envisioned for . Although there is no evidence indicating that Marginália ever reached publication, the project indicates that Barreto's thoughts evolved throughout the 1910s. Floreal certainly was an important moment in his career as a young writer, but it is Marginália that epitomises Barreto's dream as a Tolstoyan

\footnotetext{
${ }^{41}$ BARRETO, cit., vol. 15, p. 138.

${ }^{42}$ Ibidem.
} 
intellectual and magazine writer: a publication that would enable him to reach a large audience without having to conform to the commercial editorial standards of the carioca belle époque.

\section{References}

Manuscript and Primary Sources

BARRETO, Lima. Arquivo Lima Barreto. Divisão de Manuscritos, Biblioteca Nacional, Rio de Janeiro.

A.B.C. (1912). Rio de Janeiro: Typ. da Revista dos Tribunais.

Careta (1908). Rio de Janeiro: Editora Kosmos. Available at http://objdigital.bn.br/acervo_digital/div_periodicos/careta/careta_anos.htm.

Accessed on 8 June 2014.

Floreal: publicação bimensal de crítica e literatura (1907). Rio de Janeiro: Typ. Rebello Braga. Available at http://www.brasiliana.usp.br/bbd/handle/1918/69. Accessed on June 2014.

Fon-Fon (1907). Rio de Janeiro: Kosmos. Available at http://objdigital.bn.br/acervo_digital/div_periodicos/fonfon/fonfon_anos.htm.

Accessed on 8 June 2014.

O Malho (1902). Rio de Janeiro: O Malho S.A.. Available at http://objdigital.bn.br/acervo_digital/div_periodicos/malho/anuario_malho.htm.

Accessed on 8 June 2014.

Books

BARBOSA, Francisco de Assis. A vida de Lima Barreto. 9th ed. Rio de Janeiro: José Olympio, 2003.

BARRETO, Lima. [1909] Recordações do Escrivão Isaías Caminha. Edited by Francisco de Assis Barbosa, M. Cavalcanti Proença, \& Antonio Houaiss. Vol. 1. São Paulo: Brasiliense, 1956.

[1915] Triste fim de Policarpo Quaresma. Edited by Francisco de Assis Barbosa, M. Cavalcanti Proença, \& Antonio Houaiss. Vol. 2. São Paulo: Brasiliense, 1956.

[1915] Numa e a Ninfa. Edited by Francisco de Assis Barbosa, M. Cavalcanti Proença, \& Antonio Houaiss. Vol. 3. São Paulo: Brasiliense, 1956.

. [1919] Vida e morte de M. J. Gonzaga de Sá. Edited by Francisco de Assis Barbosa, M. Cavalcanti Proença, \& Antonio Houaiss. Vol. 4. São Paulo: Brasiliense, 1956.

[1948] Clara dos Anjos. Edited by Francisco de Assis Barbosa, M. Cavalcanti Proença, \& Antonio Houaiss. Vol. 5. São Paulo: Brasiliense, 1956.

[1920] Histórias e sonhos. Edited by Francisco de Assis Barbosa, M. Cavalcanti Proença, \& Antonio Houaiss. Vol. 6. São Paulo: Brasiliense, 1956. 
[1923] Os Bruzundangas. Edited by Francisco de Assis Barbosa, M. Cavalcanti Proença, \& Antonio Houaiss. Vol. 7. São Paulo: Brasiliense, 1956.

[1953] Coisas do Reino de Jambon. Eds. Francisco de Assis Barbosa, M. Cavalcanti Proença, \& Antonio Houaiss. Vol. 8. São Paulo: Brasiliense, 1956.

[1953] Feiras e mafuás. Eds. Francisco de Assis Barbosa, M. Cavalcanti Proença, \& Antonio Houaiss. Vol. 10. São Paulo: Brasiliense, 1956.

[1953] Marginália. Eds. Francisco de Assis Barbosa, M. Cavalcanti Proença, \& Antonio Houaiss. Vol. 12. São Paulo: Brasiliense, 1956.

Impressões de leitura. Eds. Francisco de Assis Barbosa, M. Cavalcanti Proença, \& Antonio Houaiss. Vol. 13. São Paulo: Brasiliense, 1956.

[1953] Diário íntimo. Eds. Francisco de Assis Barbosa, M. Cavalcanti Proença, \& Antonio Houaiss. Vol. 14. São Paulo: Brasiliense, 1956.

[1953] O cemitério dos vivos. Edited by Francisco de Assis Barbosa, M. Cavalcanti Proença, \& Antonio Houaiss. Vol. 15. São Paulo: Brasiliense, 1956.

Correspondência ativa e passiva. Eds. Francisco de Assis Barbosa, M. Cavalcanti Proença, \& Antonio Houaiss. Vol. 16. São Paulo: Brasiliense, 1956.

Correspondência ativa e passiva. Eds. Francisco de Assis Barbosa, M. Cavalcanti Proença, \& Antonio Houaiss. Vol. 17. São Paulo: Brasiliense, 1956.

Toda crônica. Eds. Beatriz Resende \& Rachel Valença. 2 volumes. Rio de Janeiro: Agir, 2004.

BROOKER, Peter; THACKER, Andrew. The Oxford Critical and Cultural History of Modernist Magazines, 3 vols. Oxford: Oxford University Press, 2009-2013.

CORRÊA, Henrique Sergio Silva. O A.B.C. de Lima Barreto (1916-1922). Unesp, Assis, MA dissertation, 2012.

JACKSON, H J.. Marginalia: Readers Writing in Books. New Haven: Yale University Press, 2001.

MELLO, Antonio de Oliveira. As minas reveladas: Paracatu no tempo. Paracatu: Prefeitura Municipal, 1994.

MOTT, Frank Luther. A History of American Magazines, 1741-1930. 5 volumes. Belknap Press of Harvard University Press, 1967.

OAKLEY, Robert J. The Case of Lima Barreto and Realism in the Brazilian 'Belle Époque'. Lewiston, N.Y.: E. Mellen Press, 1998.

ROWE, Patrick. Daumier, art for the masses: a bicentennial celebration of the birth of Honore Daumier: selected works from the Rowe Collection. Tallahassee, USA: Museum of Fine Arts, Florida State University, 2008.

SCOBIE, James R. Buenos Aires, del centro a los barrios, 1870-1910. Buenos Aires: Solar/Hachette, 1977.

TOLSTOY, Leo. What is Art? New York: Funk \& Wagnalls Company, 1904. 
FELIPE BOTELHO CORREAA (PhD, Oxford) is Lecturer in Lusophone Studies at King's College London. E-mail address: <felipe.correa@kcl.ac.uk>.

Recebido: 15.09 .2014

Aprovado: 23.10.2014 